\title{
Islamic Spiritual Deconstruction: Kanjeng Ratu Kidul Myth in Kiai Ibnu Hajar's View
}

\section{Suwito}

Institut Agama Islam Negeri (IAIN) Purwokerto, Indonesia

suwitons@iainpurwokerto.ac.id

\section{Mohammad Ulyan}

Institut Teknologi Telkom Purwokerto, Indonesia

mohammadulyan@gmail.com

\section{Ida Novianti}

Institut Agama Islam Negeri (IAIN) Purwokerto, Indonesia idanovianti@iainpurwokerto.ac.id

\section{Muflihah}

Institut Agama Islam Negeri (IAIN) Purwokerto, Indonesia mymuflie@gmail.com

\section{Abstract}

This article aims to study and analyze the Islamic spiritual sides of the deconstruction in Kanjeng Ratu Kidul belief from the perspective of Kiai Ibnu Hajar. Kanjeng Ratu Kidul is a very popular myth among people in the southern part of Java Island. Most of them hold annual ceremonies as a way to express their request for having the blessing and being avoided from disasters. The data of this research were collected through in-depth interviews and participatory observations. Derrida's deconstruction theory was applied to analyze the spirituality aspects. There are three deconstruction processes: (1) logocentric identification; (2) internal contradiction return; (3) difference or building new construction. This research found that Kiai Ibnu Hajar's deconstruction spirituality was performed in three stages: (1) visual identification stage, which is 
done through eliciting the discourse of Kanjeng Ratu Kidul by her pictures or photos; (2) returning stage, which is done through mindverbal activities, i.e. by understanding the nature and existence of human being through religious teachings and informal chats; (3) building new concept, which is actualized through the use of new terms among the members of Jamaah Aolia Panggang Mosque.

Keywords: Deconstruction, Myth, Kanjeng Ratu Kidul, Sufism, Jamaah Aolia.

\section{Abstrak}

DEKONSTRUKSI SPIRITUAL ISLAM: MITOS KANJENG RATU KIDUL DALAM PANDANGAN KIAI IBNU HAJAR. Artikel ini bertujuan untuk mengkaji dan menganalisis nilai spiritual Islam dari dekonstruksi kepercayaan Kanjeng Ratu Kidul berdasarkan perspektif Kiai Ibnu Hajar. Kanjeng Ratu Kidul adalah mitos yang sangat populer di kalangan masyarakat di bagian selatan Pulau Jawa. Kebanyakan dari mereka mengadakan upacara tahunan sebagai cara untuk mengungkapkan permintaan agar mendapat berkah dan terhindar dari bencana. Pengumpulan data dilakukan melalui wawancara mendalam dan observasi partisipatif. Teori dekonstruksi Derrida digunakan untuk menganalisis aspek spiritual. Ada tiga proses dekonstruksi yang digunakan: (1) identifikasi logosentris; (2) pembalikan kontradiksi internal; (3) differance atau pembentukan konstruksi baru. Penelitian ini menemukan bahwa dekonstruksi spiritualitas Kiai Ibnu Hajar dilakukan dalam tiga tahap: (1) tahap identifikasi visual yang dilakukan melalui penggalian wacana Kanjeng Ratu Kidul melalui gambar atau fotonya; (2) tahap pengembalian yang dilakukan melalui kegiatan pengkajian dan aktivitas verbal, seperti memahami hakikat dan keberadaan manusia melalui pengajian dan obrolan informal; (3) membangun konsep baru yang dilakukan melalui penggunaan istilah-istilah baru di kalangan anggota Masjid Jamaah Aolia Panggang.

Kata Kunci: Dekontruksi, Mitos, Kanjeng Ratu Kidul, Sufitik, Jamaah Aolia. 


\section{A. Introduction}

Javanese community ${ }^{1}$ especially in the suburbs, has belief system of myths. ${ }^{2}$ Honig Jr., as quoted by Dawami ${ }^{3}$ states that the belief in myths is the effect of supernatural metaphysic-emotional experiences. Such experience eventually drives relational treatment to the cosmos. ${ }^{4}$ It is belief in the myth that supports the practices of sesaji ceremonies, which is believed to be able to create harmony and peace of the energy of the universe. ${ }^{5}$

The most dominant myth believed by the people of South Javanese Coasts is the myth of Kanjeng Ratu Kidul. ${ }^{6}$ Kanjeng Ratu Kidul is believed to have great power. She is also believed to be able to do anything, including making any bad accident to certain people at any time and place. Psychologically, the people from generation to generation are under her power and pressure. For that reason, some people do regular ceremony as worship to Kanjeng Ratu Kidul. They believed that the worship, which is actualized in the form of labuhan, ${ }^{7}$ larung, and sesaji, will create harmony between the people and Kanjeng Ratu Kidul.

On the contrary, in Islam, the provision of sesaji for the supernatural beings is considered to break the principle of aqidah. ${ }^{8}$

${ }^{1}$ M. Bambang Pranowo, Creating Islamic Tradition in Rural Java (Monash: Monash University, 1991); M. Bambang Pranowo, Memahami Islam Jawa (Jakarta: Pustaka Alvabet, 2009).

${ }^{2}$ Kuntowijoyo, Paradigma Islam: Interpretasi untuk Aksi (Bandung: Mizan, 2008), 529-555; Lavigne, et al., "People's Behaviour in the Face of Volcanic Hazards: Perspectives from Javanese Communities, Indonesia", Journal of Volcanology and Geothermal Research 172, no. 4 (2008): 273-287; Robert Wessing, A Princess from Sunda: Some Aspects of Nyai Roro Kidul (n.pc.: Asian Folklore Studies, 1997), 317-353.

${ }^{3}$ Mohammad Dawami, Makna Agama dalam Masyarakat Jawa (Jakarta: LESFI, 2002).

${ }^{4}$ Stephen C. Headley, "Javanese Cosmogonies and Muslim Cosmographies: an Encompassing Knowledge?", Indonesia and the Malay World 28, no. 2 (2000): 280-300.

${ }^{5}$ Mohammad Dawami, Makna Agama dalam Masyarakat Jawa (Jakarta: LESFI, 2002).

${ }^{6}$ Nugroho Trisnu Barata, "Menelisik Mitos Dewi Lanjar dan Mitos Ratu Kidul dengan Perspektif Antropologi-Struktural," Forum Ilmu Sosial 40, no. 2 (2013); Roy E. Jordan, Tara and Nyai Lara Kidul: Images of the Divine Feminine in Java (n.pc.: Asian Folklore Studies, 1997), 285-312; Resink, Kanjeng Ratu Kidul: the Second Divine Spouse of the Sultans of Ngayogyakarta (n.pc.: Asian Folklore Studies, 1997), 313-316; Robert Wessing, A Princess from Sunda: Some Aspects of Nyai Roro Kidul (n.pc.: Asian Folklore Studies, 1997), 317-353.

${ }^{7}$ Abdul Jalil, "Memaknai Tradisi Upacara Labuhan dan Pengaruhnya terhadap Masyarakat Parangtritis," El-Harakah 17, no. 1 (2016): 101-113.

${ }^{8}$ Ichsan Saputro, "Resistensi Agama dan Budaya Masyarakat," Walisongo: Jurnal Penelitian Sosial Keagamaan 21, no. 2 (2013): 251-270. 
This practice can destroy Islamic aqidah and will cause them to be trapped in shirk. ${ }^{9}$

The act of shirk (worship of anyone or anything besides Allah swt.) makes the doer break the Islamic principles and even may considered to abondon Islam, especially if a Muslim believes that the spiritual beings in the ocean are able to create disasters and blessings. Many people believe that if they do not provide worship in the form of sesaji, they will feel worried about the emergence of destructive power to the people in the surrounding coastal areas. Such a belief is often found along with the coastal areas of the Hindian Ocean, i.e. along with the southern coastal areas of Java, such as in Gunung Kidul Regency, Province of Yogyakarta. For that reason, it is urgently needed that people should have a good understanding of aqidah by giving aqidah education to the people in order to avoid them from being trapped in shirk.

There has been a Sufistic strategy integrated with unique and interesting cultural activities that have been practiced for a long time by Kiai Ibnu Hajar. He has tried to deconstruct the rooted myth and it has made the society in the southern Javanese coastal areas, especially Jamaah Aolia Gunung Kidul, can make a positive relationship with the myth of KKR without being trapped in the practices that break the Islamic aqidah principles. This article is aimed at describing and analyzing the sufistic-cultural strategy done by Kiai Ibnu Hajar in relation to the KKR myth among the members of Jamaah Aolia in southern Javanese coastal areas.

\section{B. Discussion}

\section{Derrida's Deconstruction}

Etymologically, the word deconstruction is originated from de'construire (French), which means deconstruct and then

'Jan Assmann, "Monotheism and Polytheism," Religions of the Ancient World: a Guide (2004): 17-31; Jonathan Kirsch, God Against the Gods: the History of the War between Monotheism and Polytheism (London: Penguin, 2005); Umma Farida, "Pemikiran Ismail Raji al-Faruqi Tentang Tauhid, Sains, dan Seni," Fikrah 2, no. 2 (2014). 
reconstruct ${ }^{10}$ or from the word de'constructio (Latin), meaning reducing a construction. ${ }^{11}$ Terminologically, Taylor ${ }^{12}$ states that deconstruction is "certain thinking about tradition and context". Meanwhile, Parker ${ }^{13}$ defines deconstruction as "an intensely critical mode of reading systems of meaning and unraveling the way these systems work as 'texts'....' The other definition is suggested by Pujianti, ${ }^{14}$ she defines deconstruction as an act of eliminating dominating rules and opposition hierarchy. Besides, Nursalim, ${ }^{15}$ states that deconstruction is a term used by Derrida as a means of breaking the binary opposition, such as utterance or writing. The method of deconstruction started from Derrida's criticism of modern hermeneutics, which assumes that it is able to understand the meaning of a text objectively. ${ }^{16}$

In general, Derrida's criticism covers the concept of "logocentrism", 17 i.e. a metaphysic tendency to legitimate the absolute truth in a language or a phenomenon. The transcendental essence is called logocentrism because the act of reading is addressed to find the existing center of meaning. ${ }^{18}$ Mulawarman ${ }^{19}$

${ }^{10}$ David Samiyono, "Resistensi Agama dan Budaya Masyarakat," Walisongo: Jurnal Penelitian Sosial Keagamaan 21, no. 2 (2013): 251-270.

${ }^{11}$ Irfan Kurniawan, "Ketermarginalan Seni Pertunjukan Rabab Piaman di Kecamatan Lubuk Alung Pariaman Sumatera Barat," Jurnal Sitakara 4, no. 1 (2019).

${ }^{12}$ Mark C. Taylor, Deconstruction in Context: Literature and Philosophy (Chicago: University of Chicago Press, 1986).

${ }^{13}$ Ian Parker, "Deconstruction and Psychotherapy," Psychology After Deconstruction (London: Routledge, 2014), 68-79.

${ }^{14}$ Fariska Pujiyanti, "Dekonstruksi Dominasi Laki-laki dalam Novel The Da Vinci Code Karya Dan Brown,” Undergraduate Thesis, Universitas Diponegoro Semarang, 2010.

${ }^{15}$ Agus Nursalim, “Dekonstruksi Motif Batik Keraton Cirebon: Pengaruh Ragam Hias Keraton pada Motif Batik Cirebon,” Jurnal Penelitian Pendidikan 15, no. 1 (2016).

${ }^{16}$ Jonathan D. Culler, Ferdinand de Saussure (New York: Cornell University Press, 1986); Roy Harris, Language, Saussure, and Wittgenstein: How to Play Games with Words (n.pc.: Psychology Press, 1990); John E. Joseph, Saussure (Oxford: Oxford University Press, 2012).

${ }^{17}$ Zhang Longxi, “The 'Tao' and the 'Logos': Notes on Derrida's Critique of Logocentrism," Critical Inquiry 11, no. 3 (1985): 385-398; Saul Newman, “Derrida's Deconstruction of Authority," Philosophy \& Social Criticism 27, no. 3 (2001): 1-20; Richard Rorty, “Two Meanings of 'Logocentrism': a Reply to Norris," Redrawing the Lines: Analytic Philosophy, Deconstruction, and Literary Theory (1989): 204-216.

${ }^{18}$ Ronidin, "Pembacaan Dekonstruksi Cerpen Zina Karya Putu Wijaya," Puitika: Jurnal Humaniora 11, no. 1 (2015): 36-51.

${ }^{19} \mathrm{Aji}$ Dedi Mulawarman, "Nyanyian Metodologi Akuntansi ala Nataatmadja: Melampaui Derridian Mengembangkan Pemikiran Bangsa Sendiri," Jurnal Akuntansi Multiparadigma 4, no. 1 (2014): 149-164. 
states that logocentrism is a way of thinking claiming that there is legitimacy by the reference of universal and external truth. Furthermore, Kurniawan ${ }^{20}$ and Islamy ${ }^{21}$ state that logocentrism is a metaphysic system that admits the logos and transcendental conditions that happen in the phenomenal world.

Deconstruction is not only addressed to a text or writing but also to all cultural statements. This is because the statements are also texts containing values, ideology, truth, and certain objectives. Therefore, deconstruction is not limited to discourse analysis, either oral or written, but also other strengths which effectively transform the nature of discourse..$^{22}$

The stages of Derrida's deconstruction are: (a) reading a text, including identifying the opposition hierarchy in a text; (b) interpreting the text; (c) comparing the interpretation of the text; (d) finding the internal contradiction hidden behind the logics or the message of the text. Finally, those contradictions produce concepts, ideas, or a new term naved deconstructive reading. ${ }^{23}$

The above stages are similar to what Sugiharto ${ }^{24}$ explains the stages of Derrida's deconstruction strategy. The first stage is identifying a text, its hierarchy, and its oppositions. It is usually found a systematically specific term. The second stage is understanding the text by viewing backward the oppositions, for example by showing the interdependence among the opposition, or by suggesting the priviese backward. The third stage is introducing a new term or idea which is in fact cannot be categorized into the previous opposition.

${ }^{20}$ Irfan Kurniawan, "Ketermarginalan Seni Pertunjukan Rabab Piaman di Kecamatan Lubuk Alung Pariaman Sumatera Barat," Jurnal Sitakara 4, no. 1 (2019).

${ }^{21}$ Izzam Izzul Islamy, "Madzhab Tafsir Perspektif Post-Strukturalisme: Studi Kritis atas Logosentrisme Nalar Al-Qur'an Menurut Dekonstruksi Jacques Derrida," Undergraduate Thesis, IAIN Walisongo Semarang, 2012.

${ }^{22}$ Abd. Ghofur, "Analisis Dekonstruksi Tokoh Takeshi dan Mitsusaburo dalam Novel Silent Cry Karya Kenzaburo Oe Perspektif Jacques Derrida," OKARA: Jurnal Bahasa dan Sastra 8, no. 1 (2014): 57-76.

${ }^{23}$ Marcelus Ungkang, “Dekonstruksi Jaques Derrida Sebagai Strategi Pembacaan Teks Sastra," Jurnal Pendidikan Humaniora 1, no. 1 (2013): 30-37.

${ }^{24}$ Bambang I. Sugiharto, Tantangan bagi Filsafat (Yogyakarta: Kanisius, 1996). 


\section{The Discourse of Myth and Mythology}

Etymologically, mythos (Greek), myth (English), and mythe (French) means significant speech..$^{25}$ Terminologically, Zipes ${ }^{26}$ explains that "myth is a collective representation that is socially determined and then inverted so as not to appear as a cultural artifact". Meanwhile, Bremmer ${ }^{27}$ states that "myth is a traditional tale with secondary, partial reference to something of collective importance", also Hawkin argues ${ }^{28}$ that "the representation of the inner psychic drama of every individual".

A myth is also understood as a story which: (a) is related to various magical power; (b) represents a legend of an extraordinary being; (c) represents a taken for granted belief ${ }^{29}$ or blunt speech suited for assembly and battle..... ${ }^{30}$ Iskandar ${ }^{31}$ explains that a myth is a story that is delivered through a discourse. Besides, Susanti, et al. ${ }^{32}$ write that myth is belief in the society represented in stories and is developed from generation to generation. Rokhimah ${ }^{33}$ writes that a myth is a story told from generation to generation through verbal language and performances.

Social scientists, especially anthropologists, state that a myth is something a person needs to find the clarity of his surroundings and the history of his past. In this definition, a myth becomes

\footnotetext{
${ }^{25}$ Robert L. Fowler, "Mythos and Logos," The Journal of Hellenic Studies 131, no. 2 (2011): 45-66.

${ }^{26}$ Jack Zipes, "Fairy Tale as Myth as Fairy Tale," The Brothers Grimm (Berlin: Springer, 2002), 207-229.

${ }^{27}$ Jan Bremmer, "What Is a Greek Myth?", Interpretations of Greek Mythology (London and Sydney: Croom Helm, 1987), 1-8.

${ }^{28}$ Erick Hawkins, The Body Is a Clear Place (Princeton, New Jersey: Dance Horizons, 1992).

${ }^{29} \mathrm{Abd}$ Ghofur, "Analisis Dekonstruksi Tokoh Takeshi dan Mitsusaburo dalam Novel Silent Cry Karya Kenzaburo Oe Perspektif Jacques Derrida," OKARA: Jurnal Bahasa dan Sastra 8, no. 1 (2014): 57-76.

${ }^{30}$ Bruce Lincoln, "Gendered Discourses: The Early History of Mythos and Logos," History of Religions 36, no. 1 (1996): 1-12.

${ }^{31}$ Dudi Sabil Iskandar, Mitos Jurnalisme (Yogyakarta: Andi, 2016).

${ }^{32}$ Duwi Susanti, Mujiman Rus Andianto, and Furoidhatul Husniah, "Mitos Asal Usul Buah Mengkudu Tanpa Biji di Lingkungan Makam Sunan Giri," Laporan Penelitian, Universitas Jember, 2013.

${ }^{33}$ Dia Oktavia Ainur Rokhimah, "Mitos Kepahlawanan dalam Ludruk Pak Sakera di Sampang", Undergraduate Thesis, Universitas Jember, 2013.
} 
a description of reality (which cannot be reached, relatively or absolutely) in a simplified form so that it can be understood and achieved by many people. A man can only have description of his position in the cosmic arrangement through understandable information or explanation and by the description he lives his life and does activities. ${ }^{34}$

This definition contains the view of the relativeness of interpretation about a myth, i.e. a myth, however it is false, has a benefit. The functionalists, among the social scientists has similar opinion. The function of myth and mythology is to provide the meaning of life that makes a person will never feel that he has a useless life. The feeling that life is useful and has higher achievements than daily experience becomes a very important element of happiness as well as the pillar of physical and mental defense. Through understanding the meaning of life, one will be able to survive in facing all the difficulties of real life. This is because the meaning of life that is strongly held by a person will make him has hope and expectation for his future. In conclusion, the meaning of one's life is the start of human dignity. ${ }^{35}$

To control the myth, Bultmann proposed his idea in Demythologize, as quoted below:

...to this extent, the kerygma is incredible to modern man, for he is convinced that the mythical view of the world is obsolete. We are today, we expect our converts to accept not only the Gospel message, but also the mythical view of the world in which it is set. if not, does the New Testament embody a truth which is quite independent of its mythical setting? If it does, theology must undertake the task of stripping the Kerygma from its mythical framework, of "demythologizing" it. ${ }^{36}$

\footnotetext{
${ }^{34}$ Nurcholish Madjid, Islam Agama Peradaban: Membangun Makna dan Relevansi Doktrin Islam dalam Sejarah (Jakarta: Paramadina, 1995).

${ }^{35}$ Nurcholish Madjid, Islam Agama Peradaban: Membangun Makna dan Relevansi Doktrin Islam dalam Sejarah (Jakarta: Paramadina, 1995).

${ }^{36}$ Rudolf Bultmann, Kerygma and Myth, ed. Hans Werner Bartsch (New York: Harper and Row, 1961).
} 
The deconstruction of mythology in this paper is an effort to rearrange the living myths in society with a new concept. Tis is important because it can enlighten human beings.

\section{Biography of Kiai Ibnu Hajar}

Most of kiai hang on their dining room wall photos of Islamic figures. It is very rarely found a kiai who hang photos of a woman on his wall. However, a different view is found in the house of Ibnu Hajar. On his dining room wall were many pictures of young ladies with various poses as well as a photo of himself and pictures of Syaikh Abdul Qadir al-Jilani and Semar.

The full name of Kiai Ibnu Hajar is Kiai Raden Ibnu Hajar Shaleh Prenolo, but he is more popular with his nickname Kiai Ibnu Hajar. He was born in Pekalongan, a regency in the north coastal part of Central Java, Indonesia, on Saturday, December 28, 1942. He grew up in Solotiang, Maron, Purworejo Regency, Central Java. After dropped out at the last semester of the Faculty of Medicine, Gadjah Mada University, Yogyakarta, he started to live in Giriharjo, District of Panggang, Gunung Kidul Regency, Yogyakarta and has been living there since July $27,1972$.

His father, also his religion teacher, is Kiai Sholeh bin Kiai Abdul Ghani bin Kiai Yunus. The name last name Prenolo refers to the name of his great grandfather, Raden Gagak Prenolo III, Raden Gagak Prenolo II, and Raden Gagak Prenolo I. The Prenolos were buried Makam Gede in Cangkrep Purworejo. Meanwhile, his mother is Rr. Shofiyah binti Kiai R. Ibnu Sabar Pekalongan. ${ }^{37}$

After finishing his high school, Kiai Ibnu Hajar continued his study at the Faculty of Medicine, Gadjah Mada University, Yogyakarta. He decided not to finish his study for the reason that he didn't want to take benefit from those in sickness, despair, and death. In addition, he also thought that medical science could lead him to polytheism. His principal went after his father, who was also a naib

${ }^{37}$ Suwito N.S., Eko-Sufisme: Konsep, Strategi, dan Dampak (Yogyakarta and Purwokerto: Buku Litera and STAIN Press, 2011). 
(a main figure in religious affairs) in Purworejo. However, he has mastered medical science, such as how to inject, diagnose, conduct therapy, as well as small operations that have been practiced even though secretly to help people. ${ }^{38}$

He decided to stay in the Gunungkidul area to follow his future wife who was serving as a midwife in Panggang District, Gunungkidul Regency, Yogyakarta. At that time, the journey to this area could be reached on foot only, via the uphill road for approximately 4 hours from the Imogiri area, Yogyakarta. Public transportation had not yet reached Gunungkidul because of inadequate road access. ${ }^{39}$ He patiently and happily passed various challenges in life, ranging from the harsh nature, lack of water, lack of food, as well as people who are still very unfamiliar with the teachings of Islam.

In 1984 Kiai Ibnu Hajar, together with the community, established The Aolia Mosque. This is a mosque standing at the intersection of Giriharjo, Panggang. This mosque is decorated with classic ornaments that make it look as if it has existed since the 1800s. This mosque stands across the road to Parangtritis. The distinctive shape of the mosque's dome, similar to a cauldron (priuk), flattened over the top. Variations of $90 \mathrm{~cm}$ diameter circular window make the mosque feel cool. Most of the windows are decorated with yellow and green calligraphy ornaments making the graphics look contrasting. The sentence "La ilaha illa Allah" written with Panggang style give more beauty and uniqueness of this mosque. The Aolia Roast Mosque design looks like an ancient building that was built in the $1700 \mathrm{~s}^{40}$ To the west (behind) the mosque's water level is a replica of the headstone as a reminder of death. The writing "The Death in Memoriam" is displayed under the calligraphy "ذكرالموت" which means remembering death and it makes people who come to this mosque remember death. When people

\footnotetext{
${ }^{38}$ Interview with Kiai Ibnu Hajar, October 28, 2018.

${ }^{39}$ Interview with Kiai Ibnu Hajar, October 28, 2018.

${ }^{40}$ Suwito N.S., Eko-Sufisme: Konsep, Strategi, dan Dampak (Yogyakarta and Purwokerto: Buku Litera and STAIN Press, 2011).
} 
remember death, they will remember the afterlife and remember Allah swt. When a person ignores a reminder of death, it is a sign that he is stubborn whose heart functions very little. There are nine very big mirrors hang on the wall around the mosque. ${ }^{41}$

\section{Deconstruction of Kanjeng Ratu Kidul Myth}

a. Mistical Figure of Kanjeng Ratu Kidul

Kanjeng Ratu Kidul (famous with the name Ratu Kidul, Nyi Loro Kidul, or sometimes called Nyi Blorong) is believed by Javanese people (especially in southern coastal areas) as the mystical ruler of the sea and the land. She is described as a beautiful woman with green cloth and jasmine necklace, having long hair and wearing a crown on her head, passing the wild waves of the ocean.

Kanjeng Ratu Kidul is believed to have a great supernatural power, by which the people in the southern coast of Java island believe that Kanjeng Ratu Kidul is able to put a disaster and blessing to those whom she is willing to. This myth is believed from generation to generation and makes it a spiritual burden causing the believers feels under pressure.

Below are research data of Javanese southern coastal people's spiritual condition. Sastroamidjojo ${ }^{42}$ wrote that people spread flowers as a form of a worship ritual for Kanjeng Ratu Kidul with the intention of having harmony. Fatkhan ${ }^{43}$ found that the people in Java coastal areas have no bravery to wear green cloth, especially on the coast, because it is a kind of prohibition. He further explains that green clothes and jasmine necklaces are the cloth of Kanjeng Ratu Kidul and her subjects.

${ }^{41}$ Observation, October-November 2018.

${ }^{42}$ Sastroamidjojo, "The Spherical Mandala in Javanese Thought," Culture Mandala 2, no. 2 (1997): 58.

${ }^{43}$ Moch. Fatkhan, "Kearifan Lingkungan Masyarakat Lereng Gunung Merapi," Jurnal Aplikasi llmu-ilmu Agama 7, no. 2 (2006): 107-121. 
Wardani ${ }^{44}$ noted that Tamansari is the holy place where Sultan Mataram and Kanjeng Ratu Kidul, who is his spiritual wife, confidentially meet. A similar statement is given by Schlehe, ${ }^{45}$ who stated that "four Javanese kingdoms have been strengthened by an on going mystical marriage Kanjeng Ratu Kidul is said to be the consort of all rulers of Mataram". An alike idea is also mentioned by Supriyanto ${ }^{46}$ stating that Nyai Rara Kidul or Kanjeng Ratu Kidul Kencanasari is the wife of Panembahan Senapati, followed by all kings and their descendants. The marriage with Kanjeng Ratu Kidul shows that there is a power that should be harmonized and conquered to create harmony. ${ }^{47}$ Meanwhile, Walsh ${ }^{48}$ having similar content to the legend of "Kiai Sapujagad", explained the cosmology of Yogyakarta Palace for the people in the center of Java. In addition, he also stated that there is a palace for the spiritual beings facing four directions, namely The Palace of Laut Selatan (the ocean in the south of Java island), facing to the South, ruled by the spiritual being Kanjeng Ratu Kidul, the Palace of Gunung Merapi (Mount Merapi), facing to the North, and the Palace of Gunung Lawu (Mount Lawu), facing to the East, ruled by the spiritual being Kanjeng Sunan Lawu, and facing to the West is the Khayangan Dlepih Palace, located in Wonogiri, ruled by the spiritual being Sang Hyang Pramoni. If a line is drawn from Mount Merapi to Laut Selatan, there will be a line following the flow of Boyon River, which is believed as the main street for the spiritual beings to travel between the to palaces.

${ }^{44}$ Laksmi Kusuma Wardani, dkk., "City Heritage of Mataram Islamic Kingdom in Indonesia: Case Study of Yogyakarta Palace," The International Journal of Social Sciences 9, no. 1 (2013): 104-118.

${ }^{45}$ Judith Schlehe, "Anthropology of Religion: Disasters and the Representations of Tradition and Modernity," Religion 40, no. 2 (2010): 112-120.

${ }^{46}$ M.T. Supriyanto, "The Magis Religious Aspect of the Anglir Mendhung Srimpi in the Court of Surakarta," Harmonia: Journal of Arts Research and Education 2, no. 2 (2001).

${ }^{47} J a l i l$, "Memaknai Tradisi Upacara Labuhan dan Pengaruhnya terhadap Masyarakat Parangtritis," El-Harakah 17, no. 1 (2016): 101-113.

${ }^{48}$ Dylan Walsh, "Kepercayaan Masyarakat Jawa terhadap Gunung," http://www. acicis.murdoch.edu.au (2000). 
Kanjeng Ratu Kidul became a mystically frightening figure for most of the southern coast Javanese. Besides being believed to have supernatural magical abilities, Kanjeng Ratu Kidul is also become the figure for Javanese who deliberately establish relationships for wealth, ${ }^{49}$ career, and health.

b. Kiai Ibnu Hajar's Spiritual Deconstruction

Kiai Ibnu Hajar deconstructs the belief of his congregation (Jamaah Aolia) through some phases. The phases are text identification, comprehension and reinforcement, new concept construction, and actualization.

The ultimate goals of all phases are: (1) being safe in this world and in the hereafter; (2) getting the pleasure of Allah swt.; (3) having the end of a good life (khusnul khatimah). These three points can be achieved if the main condition is fulfilled, i.e. commitment to monotheism and Sharia implementation. People's belief in Kanjeng Ratu Kidul is one of the obstacles to achieve these three points. This is because the community still strongly holds the belief that Kanjeng Ratu Kidul has power like God, which can provide benefits and harms to humans.

According to Kiai Ibnu Hajar, there should be a deconstruction of people's beliefs about Kanjeng Ratu Kidul. The belief of the people in Panggang and Gunungkidul should be deconstructed to meet the teaching of Al-Qur'an and Hadith. One of the ways he did is by a Spiritual-Cultural mixed approach.

The way Kiai Ibnu Hajar deconstructed the belief of the people was very unique. He hangs pictures or paintings of beautiful women. In the beginning, there was one painting of

${ }^{49}$ Onesius Otenieli Daeli, "Pesugihan: Hubungan Uang dan Mistik dalam Perspektif Antropologis," Extension Course Filsafat (ECF) 9, no. 1 (2015); Nanum Sofia and Johana E. Prawitasari, "Subjective Well-Being on Javanese Peoples that Practice Pesugihan: an Indigeneous Psychology," Lembaga Telematika Indonesia and CRC Press, Taylor, and Francis (2016). 
a beautiful woman wearing a green cloth, on a canvas of 80 $\mathrm{cm}$ x $40 \mathrm{~cm}$. Kiai Ibnu Hajar said the painting was given by a painter who once came to his house bringing three paintings of Kanjeng Ratu Kidul. The coming of the painter was driven by his dream telling him that he had to bring the painting to Kiai Ibnu Hajar in order to be verified. Kiai Ibnu Hajar then chose one of the paintings that look most similar to Kanjeng Ratu Kidul. The chosen painting then was given to Kiai Ibnu Hajar and was hung on his house wall, while the others were burnt. Until now, the painting is still hanging on the wall.

This is the early spiritual-cultural-based deconstructive strategy done by Kiai Ibnu Hajar. He intentionally hangs the pictures of Kanjeng Ratu Kidul whom most people are usually afraid of. The picture always attacts the guests visiting his house, with not the exceptions of the members of his congregation, to talk about, or at least it raises their curiosity by asking questions like: (1) who is she?; (2) is there other ruler/authority in the South Ocean instead of her?; (3) does she have te power that many people make it a myth? Since the year 2011, there have been more pictures of beautiful women. Besides the picture of Kanjeng Ratu Kidul, there is also the picture of Dewi Lanjar, the ruler of the North Sea, Nawang Wulan, Dewi Ratih, and others.

Beginning from the pictures, Kiai Ibnu Hajar tried to deconstruct people's understanding about Kanjeng Ratu Kidul. According to Kiai Ibnu Hajar, there are eight queens in the South Ocean, known as Kanjeng Ratu Kidul. How Kiai Ibnu Hajar and the queens met was unique. At that time, Kiai Ibnu Hajar was curious about their power and existence. To fulfill his curiosity, Kiai Ibnu Hajar did meditation to meet them. Finally, one of them appeared and met him in his ritual. Kiai Ibnu Hajar was asked about the intention of his willingness to meet them. Kiai Ibnu Hajar stated that he wanted to meet to invite them to be believers of Allah swt. and follow the teachings of Prophet Muhammad saw. Kanjeng 
Ratu Kidul admired his intention which is different from that of other people's previous arrival. Most of the people who came to Kanjeng Ratu Kidul just asked for wealth, career, and marriage. Knowing this fact, Kanjeng Ratu Kidul said, "You are the one I have been waiting for."

Furthermore, Kiai Ibnu Hajar explained that after the meeting eight Kanjeng Ratu Kidul embraced Islam (taslim) by reciting syahadat under the guidance of Kiai Ibnu Hajar. Until now, Kiai Ibnu Hajar's congregation feels that the eight Kanjeng Ratu Kidul are members of the congregation of Aolia Mosque. The eight Kanjeng Ratu Kidul sincerely become Kiai Ibnu Hajar's guardians in any of his journey. At the time when all eight Kanjeng Ratu Kidul have embraced Islam (taslim) and become his sincere guardians and they entered the territory of the North Sea, which is under the rule of Dewi Lanjar, the troops of both territories, i.e. the South Ocean and the North Sea will fight. As the fight happened, Kiai Ibnu Hajar directly harmonized them and asked them not to fight each other. Since that moment, the North Sea spiritual inhabitants, declared to embrace Islam (taslim) and recited syahadat. Finally, the rulers of the North Sea and the out Ocean, consisting of nine spiritual beings, agreed to live peacefully and became the members of Aolia Mosque Congregation. In addition, they divided the area of guarding Kiai Ibnu Hajar and the members of Aolia Mosque Congregation. If Kiai Ibnu Hajar or the members of congregation were in the the southern area of Kendeng Mount, the reponsibility for guarding them is taken by Kanjeng Ratu Kidul and the followers, while when they are in the northern area the guarding work is taken by Dewi Lanjar and her followers.

Kiai Ibnu Hajar stated that he never asked Kanjeng Ratu Kidul or Dewi Lanjar to guard him and his congregation. According to him, spiritual beings or jin, like Kanjeng Ratu Kidul and Dewi Lanjar, cannot be asked for anything, except for having a belief in God. It was only Prophet Sulaiman 
a.s. who could ask and command a jin; others are totally prohibited to do so. If a person asked a jin for fulfilling his demand, his tauhid will be trapped in such a practice.

The above explanation shows that the deconstruction has achieved the main process. This means that the previous belief about Kanjeng Ratu Kidul-who was believed as a spiritual being or jin who have huge power-was deconstructed by Kiai Ibnu Hajar through giving the people different perception about Kanjeng Ratu Kidul and Dewi Lanjar. The new perception is that they are already included as the members of Aolia Mosque Congregation because they have embraced Islam and they need no more sesaji (worship) from the people. In addition, Kiai Ibnu Hajar informed that their crown had already had different appearance, i.e. the existance of the writing Allah swt. at the front.

Furthermore, Kiai Ibnu Hajar said that in the 2016 hajj season, there were 43 jins (Kanjeng Ratu Kidul, Dewi Lanjar and their guards) taking part in the hajj with Kiai Ibnu Hajar. At first, they offered to Kiai Ibnu Hajar to make hajj with jin-style journeys, but it was rejected by Kiai Ibnu Hajar on the grounds that he was an ordinary human being and had to travel normally. Finally, all the jin boarded the plane with Kiai Ibnu Hajar without being seen by common people. After returning the pilgrimage, according to Kiai Ibnu Hajar, at this time, Dewi Lanjar and Kanjeng Ratu Kidul had veiled and Dewi Lanjar was called by her caretaker with a new title, namely hajjah.

The things currently carried out continuously by the Kanjeng Ratu Kidul are reciting zikr, bismillah, alhamdulillah, Allahu akbar, inna lillahi wa inna ilaihi raji'un, each as much as 10.000 times each day. In addition, they no longer need human offerings such as barrels, harbor, and so on. Instead she is angry if there are people who consider her as God who must be given offerings, worshiped, and deified. 
According to Kiai Ibnu Hajar, Kanjeng Ratu Kidul and Dewi Lanjar have now become the righteous servants of God. They were made by Allah swt. as the waliyullah of the jin who always preached to his subordinates. With this explanation, finally members of the Aolia Mosque Congregation had begun to "make friends" with Kanjeng Ratu Kidul and Dewi Lanjar with the usual friendly relations between creatures of God, without any offerings (sesaji) to be given. Indeed there is still one extraordinary power that Kiai Ibnu Hajar always clashed with, namely Blorong. According to Kiai Ibnu Hajar, Blorong is a kind of devil, she is not just an ordinary genie. But she is a devil who is no longer going to live. However, his strength has been paralyzed by Kiai Ibnu Hajar, and several times her palace was ransacked by Kiai Ibnu Hajar because of her error. According to Kiai Ibnu Hajar, she was given fadlal by Allah swt. to spread Islamic values (da'wah) in two worlds (atstsaqalain), they were human world and spiritual creatures world. Some genies had declared their faith to Allah swt. like Kanjeng Ratu Kidul, Dewi Lanjar, Dewi Nawang Wulan, Dewa Wisnu, even the spiritual creartures from Kathmandu or Arabian peninsula.

The relationship built by humans and jin is explained by Kiai Ibnu Hajar as follows:

"Manusia itu kualitasnya ibarat emas 24 karat, sementara bangsa adalah perak. Kalau manusia justru minta pertolongan pada jin, itu sangat naif karena derajatnya pasti turun menjadi sekarat (satu karat) bahkan menjadi perak. Harusnya jin yang meningkatkan kualitasnya seperti manusia yang saleh. Jadi, kalau kita minta kepada jin, dari 24 karat menjadi sekarat. Tetapi kalau jin ikut manusia, dapat pengaruhnya emas, naik kelasnya. Kalau jin ikut diri kita, naik kelasnya. Kalau kita ikut jin, turun kelasnya."

(Human's quality is like 24 carat gold, while jin's is like silver. If a human being ask for help to jin, it is really odd behaviour because his/her quality will decrease into one carat, or even to the level of silver. The ideal condition is the jin who should 
increase their quality to the level of human. So, if a human being ask to help jin, his quality decreases from 24 carats to 1 carat. On the contrary, if jins follow human being, they will get the influence from the gold level, and it will increase their level. If we (human being) follow jins, our quality level will decrease). ${ }^{50}$

Further, Kiai Ibnu Hajar explained:

"Dalam sejarah kenabian dan rasul, belum pernah ada rasul dari golongan jin. Mereka selalu nebeng mengikuti kenabian dan kerasulan manusia."

(In the history of prophecy, there had never been a prophet from jin community. Jins were always in the position of following the prophecy of human being). ${ }^{51}$

The way Kiai Ibnu Hajar explain the figure of Kanjeng Ratu Kidul, which is in accordance with aqidah and tauhid values, has made the members of congregation do not feel scared to the figure of Kanjeng Ratu Kidul. In addition, from Kiai Ibnu Hajar's explanation, it is shown that many of human beliefs are false, as there are many people ask for wealth in South Ocean.

In Kiai Ibnu Hajar perception, all the creatures of Allah swt. will not be able to create any loss or advantage without Allah's permission. Neither jin, satan, nor angels cannot take the soul of human being without God's permission. This is the point that Kiai Ibnu Hajar emphasizes, i.e. human beings does not need to be afraid of other creatures, not the exception Kanjeng Ratu Kidul and Blorong. This is because they all are also the creatures of Allah swt. Consequently, the only way to ask for help is only to Allah swt., the Safety Giver.

As seen from Derrida's deconstruction theory, Kiai Ibnu Hajar's explanation about Kanjeng Ratu Kidul is a text of a myth

${ }^{50}$ Interview with Kiai Ibnu Hajar, May 17, 2019.

${ }^{51}$ Interview with Kiai Ibnu Hajar, May 17, 2019. 
that has been the belief of the community. At first, in the myth about Kanjeng Ratu Kidul, there was a deviant value of aqidah, but it eventually meets the value of Islamic aqidah (the relation between human and Allah swt., the relation between human and jin) among the member of Aolia Mosque Congregation.

The foundation of tauhid is given by Kiai Ibnu Hajar to the congregation and the patients who visit his house. Before and after the public speech (pengajian) Kiai Ibnu Hajar always drops in one of the members' houses, where there are about 20 people gather and chat, while waiting for the pengajian start. At this moment, Kiai Ibnu Hajar often allows people to ask question about the problems they face.

The members of the community, especially those who join Aolia Mosque Congregation, have known the difference between Kanjeng Ratu Kidul and Nyai Blorong. Nyai Blorong is an iblis to whom people ask for wealth, career position, marital partner, health, etc. ${ }^{52}$ Common people often think that Kanjeng Ratu Kidul and Nyai Blorong are the same figures. In fact, both figures are believed to have the authority of the South Ocean. However, there is a real difference between them, namely in relation to tauhid. Explaining this fact, Kiai Ibnu Hajar stated, "Fostering the community must be done with wisdom and through good means. In inviting people to abandon existing beliefs and habits, do not be hasty, but little by little. As Muslims, they must be able to behave according to Islamic teachings." ${ }^{53}$ Providing understanding to the community cannot be done radically, but it should be done gradually. Installing the belief in monotheism requires more time than building the human relationship (mu'amalah). Setting strategies and tactics to understand the community is the key to success in $d a^{\prime} w a h$. Sometimes a preacher needs to camouflage to infiltrate the opponent in order to raise doubt

${ }^{52}$ Interview with Kiai Ibnu Hajar, May 17, 2019.

${ }^{53}$ Interview with Kiai Ibnu Hajar, May 17, 2019. 
about the fallacy of the previous teachings. Camouflage is used to foster awareness from within. ${ }^{54}$

In the context of deconstruction, the display of Kanjeng Ratu Kidul paintings, Dewi Lanjar, and other genie pictures in the living room of Kiai Ibnu Hajar's and its worshipers' houses is a way to deconstruct the myth of Kanjeng Ratu Kidul "from within". At first glance, it will be seen that they are fanatical followers of Kanjeng Ratu Kidul. The painting becomes a tool to uncover the meaning that is in the myth of Kanjeng Ratu Kidul itself. Demolition of the meaning uses elements from "in the text" itself.

The deconstruction process of the mythical Kanjeng Ratu Kidul by Kiai Ibnu Hajar can be described in the following table.

Table 1

Deconstruction Process of the Mythical Kanjeng Ratu Kidul by Kiai Ibnu Hajar

\begin{tabular}{|c|c|}
\hline Derrida's Deconstruction & Kiai Ibnu Hajar's Deconstruction \\
\hline - Logocentrism & $\begin{array}{ll}\text { - } & \text { Kanjeng Ratu Kidul: a creature } \\
\text { - } & \text { Human following genie = decreasing his } \\
\text { degree }\end{array}$ \\
\hline $\begin{array}{l}\text { - Reversal of internal } \\
\text { contradictions }\end{array}$ & $\begin{array}{ll}\text { - } & \text { Kanjeng Ratu Kidul: faithful, taslim } \\
\text { - } & \text { Need no offerings/sesaji }\end{array}$ \\
\hline $\begin{array}{l}\text { - Difference/new } \\
\text { construction/concept }\end{array}$ & $\begin{array}{ll}\text { - } & \text { People give no more offerings to } \\
\text { Kanjeng Ratu Kidul } \\
\text { - } \quad \text { People have no fraud of Kanjeng Ratu } \\
\text { Kidul anymore, even consider Kanjeng } \\
\text { Ratu Kidul as 'friend' } \\
\text { - } \quad \text { Tauhid-based community is created }\end{array}$ \\
\hline
\end{tabular}

The logocentrism that has been built in the perception of the general public so far in understanding Kanjeng Ratu

${ }^{54}$ Interview with Kiai Ibnu Hajar, May 17, 2019. 
Kidul as the ruler of the South Sea who asks for offerings every year is slowly being dismantled through strong argumentation. The postponement of the word "Kanjeng Ratu Kidul" (signficant/"form") with the signfied "postponed" is then given a new meaning. This makes the existing beliefs (existing beliefs) in the public perception messy.

Kiai Ibnu Hajar's phrase was like, "He said in the South Sea there were many demits, apparently not", "Who knows, meeting Nyai Blorong would give money", "The devil began to operate", "That is not a painting of Nyai Roro Kidul, but Kanjeng Ratu Kidul", "Slowly undermines the established", "Text arrangement". By playing with the sign, the sign or reference to be deduced from a text is automatically delayed. Dissemination of the sign makes the entire text order that had been stable becomes messy.

Kanjeng Ratu Kidul who had been considered as a god and seemed to defeat the role of God was overhauled according to the foundation of monotheism. Kanjeng Ratu Kidul is a creature of God who comes from the jin group. Jins have faith and some deny it.

That is where the relationship between the markers is mocked so that a difference appears between the two. In that way, Kiai Ibnu Hajar overhauled the entire mythical building Kanjeng Ratu Kidul. In general, the process of deconstructing the myth of Kanjeng Ratu Kidul can be seen from the chart below.

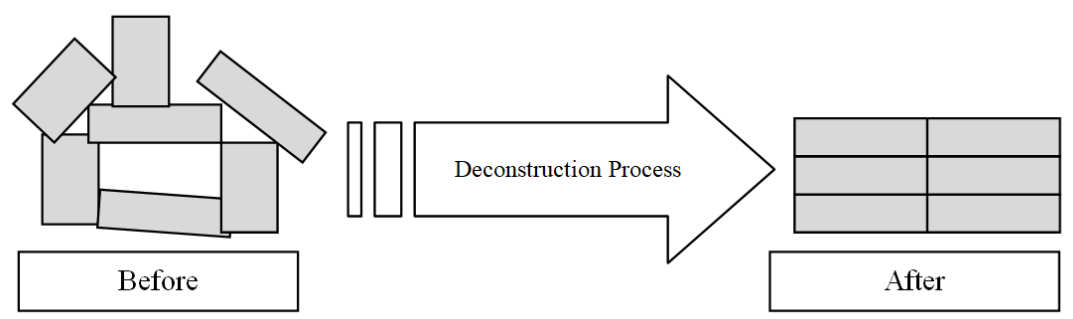

Figure 1

Kanjeng Ratu Kidul's Myth Deconstruction Process 
Deconstruction of the myth of Kanjeng Ratu Kidul uses "property" which originates from within the "text" itself. Debris "text" is arranged into a new building construction that is different from the previous building but does not "throw" the constituent materials.

In viewing the offerings such as in the ceremony called labuhan, larungan, or sedekah laut, Kiai Ibnu Hajar stated that the practice was just a useless one (mubadzir) and it won't be accepted from aqidah point of view nor logics. This is clearly seen in Kiai Ibnu Hajar's statement as follows.

"Apa artinya kepala kerbau satu untuk Lautan Hindia yang begitu luas, tak ada artinya. Kalau dikasih pelet ratusan ton itu baru ada pengaruhnya. Lautan kan tidak usah memberi makan, tidak perlu menernak ikan, sudah besar-besar semua dikasih oleh Tuhan, kurang apa coba? Tapi disuruh syukur pada susah, malah makanan enak pada dibuang ke laut. Di kasih jarit (kain) juga, apa Kanjeng Ratu Kidul itu telanjang?"

(What is the meaning of a buffalo head to Hindian Ocean, which is so huge? If we give hundreds tons of food for the fish, it may bring some effects. The ocean does not need any food, we don't need to breed the fish, they can grow up by themselves. All are given by God? All are available. However, people are reluctnt to thank God, and delicious foods are thrown away to the ocean). ${ }^{55}$

The society belief about the myth of Kanjeng Ratu Kidul as explained above was deconstructed by Kiai Ibnu Hajar. The previous belief that public understanding of the figure of Kanjeng Ratu Kidul who is exalted as the lord of spirits who can deliver havoc and prosperity is denied by Kiai Ibnu Hajar. Kiai Ibnu Hajar often said that there is no power for a creature to be able to give harm, benefit, kill, revive, and not awaken. So everything that happens is the will and permission of Allah, not absolute because of the creature.

${ }^{55}$ Interview with Kiai Ibnu Hajar, May 17, 2019. 
However, many people usually connect something that happens so that it seems to be like a causal relationship. For example, natural disasters are associated with not giving offerings in a place as well as the blessing of fortune associated with the Larungan Ceremony. In addition, related to the provision of these offerings, Kiai Ibnu Hajar argued that this was Kiai Ibnu Hajar argued that it was something that was redundant and could not be accepted in terms of aqidah and logic.

\section{Conclusion}

Deconstruction was carried out by Kiai Ibnu Hajar with three processes, namely logocentric identification, a reversal of internal contradictions and differences, or the formation of new constructs. The process of identifying signs or logos that lead to basic ideas, both physically carried out with media images or symbols that provoke conversation. There are many pictures of mythological figures and artifacts (keris, spears, and magical objects). Furthermore, the results of the identification are compared in contrast to the understanding done through casual chatting while waiting for the recitation or recitation. In this context, Kiai Ibnu Hajar emphasized that Kanjeng Ratu Kidul is a human-like creature who was given the mandate as auliya'. There is a sign of monotheism on the crown. A contrast comparison is made that Kanjeng Ratu Kidul is not a ruler who must be served with offerings in the form of food provision called labuhan and larungan. This belief formed a new monotheistic construction and was under with Islamic teachings. 


\section{REFERENCES}

Assmann, Jan. "Monotheism and Polytheism." Religions of the Ancient World: a Guide (2004): 17-31.

Barata, Nugroho Trisnu. "Menelisik Mitos Dewi Lanjar dan Mitos Ratu Kidul dengan Perspektif Antropologi-Struktural." Forum Ilmu Sosial 40, no. 2 (2013).

Bremmer, Jan. "What Is a Greek Myth?" Interpretations of Greek Mythology. London and Sydney: Croom Helm, 1987.

Bultmann, Rudolf. Kerygma and Myth, ed. Hans Werner Bartsch. New York: Harper and Row, 1961.

Culler, Jonathan D. Ferdinand de Saussure. Cornell: Cornell University Press, 1986.

Daeli, Onesius Otenieli. "Pesugihan: Hubungan Uang dan Mistik dalam Perspektif Antropologis." Extension Course Filsafat (ECF) 9, no. 1 (2015).

Dawami, Mohammad. Makna Agama dalam Masyarakat Jawa. Jakarta: LESFI, 2002.

Farida, Umma. "Pemikiran Ismail Raji al-Faruqi Tentang Tauhid, Sains, dan Seni." Fikrah 2, no. 2 (2014).

Fatkhan, Moch. "Kearifan Lingkungan Masyarakat Lereng Gunung Merapi." Jurnal Aplikasi llmu-ilmu Agama 7, no. 2 (2006): 107-121.

Fowler, Robert L. "Mythos and Logos." The Journal of Hellenic Studies 131, no. 2 (2011): 45-66.

Ghofur, Abd. "Analisis Dekonstruksi Tokoh Takeshi dan Mitsusaburo dalam Novel Silent Cry Karya Kenzaburo dalam Perspektif Jacques Derrida." OKARA: Jurnal Bahasa dan Sastra 8, no. 1 (2014): 57-76.

Harris, Roy. Language, Saussure, and Wittgenstein: How to Play Games with Words. n.pc.: Psychology Press, 1990. 
Hawkins, Erick. "The Body Is a Clear Place." Dance Horizons, Princeton, New Jersey. Princeton, New Jersey: Dance Horizons, 1992.

Headley, Stephen C. "Javanese Cosmogonies and Muslim Cosmographies: an Encompassing Knowledge?" Indonesia and the Malay World 28, no. 82 (2000): 280-300.

Iskandar, Dudi Sabil. Mitos Jurnalisme. Yogyakarta: Penerbit Andi, 2016.

Islamy, Izzam Izzul. “Madzhab Tafsir Perspektif Post-Strukturalisme: Studi Kritis atas Logosentrisme Nalar Al-Qur'an Menurut Dekonstruksi Jacques Derrida." Undergraduate Thesis, IAIN Walisongo Semarang, 2012.

Jalil, Abdul. "Memaknai Tradisi Upacara Labuhan dan Pengaruhnya terhadap Masyarakat Parangtritis." El-Harakah 17, no. 1 (2016): 101-113.

Jordan, Roy E. Tara and Nyai Lara Kidul: Images of the Divine Feminine in Java. n.pc.: Asian Folklore Studies, 1997.

Joseph, John E. Saussure. Oxford: Oxford University Press, 2012.

Kirsch, Jonathan. God against the Gods: The History of the War between Monotheism and Polytheism. London: Penguin, 2005.

Kuntowijoyo. Paradigma Islam: Interpretasi Untuk Aksi. Bandung: Mizan, 2008.

Kurniawan, Irfan. "Ketermarginalan Seni Pertunjukan Rabab Piaman di Kecamatan Lubuk Alung Pariaman Sumatera Barat." Jurnal Sitakara 4, no. 1 (2019).

Lavigne, Franck, Benjamin De Coster, Nancy Juvin, François Flohic, Jean-Christophe Gaillard, Pauline Texier, Julie Morin, and Junun Sartohadi. "People's Behaviour in the Face of Volcanic Hazards: Perspectives from Javanese Communities, Indonesia." Journal of Volcanology and Geothermal Research 172, no. 3-4 (2008): 273-287. 
Lincoln, Bruce. "Gendered Discourses: The Early History of Mythos and Logos." History of Religions 36, no. 1 (1996): 1-12.

Longxi, Zhang. "The Tao and the Logos: Notes on Derrida's Critique of Logocentrism." Critical Inquiry 11, no. 3 (1985): 385-398.

Madjid, Nurcholish. Islam Agama Peradaban: Membangun Makna dan Relevansi Doktrin Islam dalam Sejarah. Jakarta: Paramadina, 1995.

Mulawarman, Aji Dedi. "Nyanyian Metodologi Akuntansi ala Nataatmadja: Melampaui Derridian Mengembangkan Pemikiran Bangsa Sendiri." Jurnal Akuntansi Multiparadigma 4, no. 1 (2014): 149-164.

Newman, Saul. "Derrida's Deconstruction of Authority." Philosophy and Social Criticism 27, no. 3 (2001): 1-20.

Nursalim, Agus. "Dekonstruksi Motif Batik Keraton Cirebon: Pengaruh Ragam Hias Keraton Pada Motif Batik Cirebon." Jurnal Penelitian Pendidikan 15, no. 1 (2016).

Parker, Ian. "Deconstruction and Psychotherapy." Psychology After Deconstruction. London: Routledge, 2014.

Pranowo, M. Bambang. Creating Islamic Tradition in Rural Java. Monash: Monash University, 1991.

Memahami Islam Jawa. Jakarta: Pustaka Alvabet, 2009.

Pujiyanti, Fariska. "Dekonstruksi Dominasi Laki-laki dalam Novel The Da Vinci Code Karya Dan Brown." Undergraduate Thesis, Universitas Diponegoro Semarang, 2010.

Resink, G.J. Kanjeng Ratu Kidul: The Second Divine Spouse of the Sultans of Ngayogyakarta. n.pc.: Asian Folklore Studies, 1997.

Rohkimah, Dia Oktavia Ainur. "Mitos Kepahlawanan dalam Ludruk Pak Sakera di Sampang." Undergraduate Thesis, Universitas Jember, 2013.

Ronidin. "Pembacaan Dekonstruksi Cerpen Zina Karya Putu Wijaya." Puitika Jurnal Humaniora 11, no. 1 (2015): 36-51. 
Rorty, Richard. "Two Meanings of Logocentrism: a Reply to Norris." Redrawing the Lines: Analytic Philosophy, Deconstruction, and Literary Theory (1989): 204-216.

Samiyono, David. "Resistensi Agama dan Budaya Masyarakat."

Walisongo: Jurnal Penelitian Sosial Keagamaan 21, no. 2 (2013): 251-270.

Saputro, Ichsan. "Konsep Tauhid Menurut Abdul Karim Amrullah dan Implikasinya terhadap Tujuan Pendidikan Islam." AtTa'dib 11, no. 2 (2016): 259-284.

Sastroamidjojo, M.S.A. "The Spherical Mandala in Javanese Thought." Culture Mandala 2, no. 2 (1997).

Schlehe, Judith. "Anthropology of Religion: Disasters and the Representations of Tradition and Modernity." Religion 40, no. 2 (2010): 112-120.

Setyawan, Anton Budi. "Dekonstruksi Benda Sehari-hari dalam Karya Seni Lukis." Invensi 2, no. 2 (2017): 61-71.

Sofia, Nanum, and Johana E. Prawitasari. "Subjective Well-Being on Javanese Peoples That Practice Pesugihan: an Indigeneous Psychology." Lembaga Telematika Indonesia and CRC Press, Taylor, and Francis, 2016.

Sugiharto, Bambang I. Tantangan bagi Filsafat. Yogyakarta: Kanisius, 1996.

Supriyanto, M.T. "The Magis Religious Aspect of the Anglir Mendhung Srimpi in the Court of Surakarta." Harmonia: Journal of Arts Research and Education 2, no. 2 (2001).

Susanti, Duwi, Mujiman Rus Andianto, and Furoidhatul Husniah. "Mitos Asal-Usul Buah Mengkudu Tanpa Biji di Lingkungan Makam Sunan Giri." Laporan Penelitian, Universitas Jember, 2013.

Suwito, N.S. "Eko-Sufisme Studi Tentang Usaha Pelestarian Lingkungan pada Jama'ah Mujahadah Ilmu Giri dan Jama'ah Aolia Jogjakarta." Disertasi, Universitas Islam Negeri Syarif Hidayatullah Jakarta, 2010. 
Suwito NS. Eko-Sufisme: Konsep, Strategi, dan Dampak. Yogyakarta dan Purwokerto: Buku Litera dan STAIN Press, 2011.

Taylor, Mark C. Deconstruction in Context: Literature and Philosophy. Chicago: University of Chicago Press, 1986.

Ungkang, Marcelus. "Dekonstruksi Jaques Derrida Sebagai Strategi Pembacaan Teks Sastra." Jurnal Pendidikan Humaniora 1, no. 1 (2013): 30-37.

Walsh, Dylan. "Kepercayaan Masyarakat Jawa Terhadap Gunung." http://www.acicis.murdoch.edu.au, 2000.

Wardani, Laksmi Kusuma, R.M. Soedarsono, Timbul Haryono, and Djoko Suryo. "City Heritage of Mataram Islamic Kingdom in Indonesia: Case Study of Yogyakarta Palace." The International Journal of Social Sciences 9, no. 1 (2013): 104-118.

Wessing, Robert. A Princess from Sunda: Some Aspects of Nyai Roro Kidul. n.pc.: Asian Folklore Studies, 1997.

Zipes, Jack. "Fairy Tale as Myth as Fairy Tale." The Brothers Grimm. Berlin: Springer, 2002. 